\title{
Evaluation of Sap Flow Sensors to Measure the Transpiration Rate of Plants during Canopy Wetting and Drying
}

\author{
Jasim Uddin (Corresponding author) \\ National Centre for Engineering in Agriculture \\ University of Southern Queensland, Toowoomba, Qld 4350, Australia \\ Tel: 61-746-873-966Ｅ-mail: mdjasimu@usq.edu.au \\ Rod Smith, Nigel Hancock and Joseph Foley \\ National Centre for Engineering in Agriculture \\ University of Southern Queensland, Toowoomba, Qld 4350, Australia
}

Received: July 3, 2014 Accepted: July 20, 2014

doi:10.5296/jas.v2i2.6134ＵRL: http://dx.doi.org/10.5296/jas.v2i2.6134

\begin{abstract}
Accurate measurement of transpiration is required to estimate the various components of evaporation losses during sprinkler irrigation. Among the methods, sap flow measurements have widely used for direct measurements of transpiration rate in plant. To evaluate the applicability of this method to field experiments involving canopy wetting (by sprinkler irrigation), stem flow measurements were compared with transpiration values estimated from successive mass measurements of small potted plants using pre-calibrated mini-lysimeters in a glasshouse at the University of Southern Queensland, during the period August-October 2010. From this study it was found that when the canopy was dry, the sap flow measurements mirrored the transpiration rate of plants with reasonable accuracy, overestimating the transpiration rate by about $11 \%$. The measurements showed no evidence of time lag between sap flow and transpiration. Following wetting of the plant canopy the sap flow declined rapidly reflecting a decline in the transpiration rate transpiration and sap flow. Location of the sap flow gage on the stem was seen to be a factor with gages at different heights giving different sap flow rates again due to the buffering capacity of the stem.
\end{abstract}

Keywords: Sap flow, Transpiration, Evapotranspiration, Sprinkler irrigation, Time lag, 
Mini-lysimeter.

\section{Introduction}

Partitioning of evapotranspiration (ET) from sprinkler irrigated cropping into its different components (transpiration, canopy evaporation, droplet evaporation and soil evaporation) is not common practice due to limitations of the traditional measurement techniques. However, Uddin et al., (2010) conceptualised that quantification of the different components of ET during sprinkler irrigation is possible using simultaneous measurements of ET (precision energy balance/eddy covariance) and sap flow. Among the components, transpiration plays a different role in evapotranspiration during irrigation and non-irrigation periods. It is the dominant component of ET between irrigations, (Lawrence et al., 2007), whereas during sprinkler irrigation, canopy evaporation is assumed to be the dominant component followed by transpiration, soil evaporation and droplet evaporation (Thomson et al., 1997). It has been suggested that transpiration can be decreased by 50-70\% during sprinkler irrigation (Cavero et al., 2009; Martinez-Cob et al., 2008) while canopy evaporation can be increased more than $50 \%$ (Thompson et al., 1997) largely due to the wet canopy evaporation.

There are two approaches available to estimate the quantity of water transpired by a plant canopy (Chabot et al., 2005). In the first approach the atmospheric demand in terms of reference evapotranspiration is determined on the basis of meteorological data and then combined it with a specific crop coefficient for the specific crop. The second approach consists of direct measurement of transpiration using sap flow sensor. The first approach is not applicable to estimate the transpiration during sprinkler irrigation, despite the fact that during the sprinkler irrigation, the transpiration is suppressed significantly to a value well below that represented by the atmospheric demand. It is also not possible to measure the transpiration during irrigation using lysimetry due to the continuous addition of water to the lysimeter during the overhead irrigation (Martinez-Cob et al., 2008; Thomson et al., 1997). Therefore, the only potential way to infer the rate of transpiration during sprinkler irrigation is by measurement of sap flow. In this method, the transpiration rate for whole plants is determined by measuring the rate at which sap ascends stems (Smith and Allen, 1996). Swanson (1994) reported that sap flow measurement has several advantages including relative ease of use, ease of automation, capacity for real time measurements over a period of time as short as necessary, and the measurement of the transpiration term separate of the components of ET (Chabot et al., 2005).

Several sap flow measurement methods have been developed by many authors (e. g., Dugas, 1990; Smith and Allen, 1996). Among these, the heat balance method developed by Sakuratani (1981) is widely used and is perceived to offer some advantages over other methods. For example, it requires no calibration or stem intrusion by temperature probes. Nevertheless, some authors (Dugas, 1990; Ham et al., 1990; Chabot et al., 2005) have indicated that sap flow methods overestimate the transpiration rate of the plants. Others (e.g. Fichtner and Schulze, 1990; Kostner et al., 1998; Schulze et al., 1985) have identified that there is a lag between sap flow and transpiration which is attributed to the capacitance or water buffering capacity of the plant. This latter factor is likely to be of particular importance in dynamic situations involving wetting and drying of the canopy where rapid changes in transpiration occur. Hence, it is 
important to determine the correlation between transpiration and sap flow before attempting field measurements that rely on the accuracy of sap flow measurement.

Although glasshouse experiments have been conducted to assess the accuracy of the sap flow sensors (e.g. Dugas, 1990) in normal (dry canopy) condition, the literature does not report any study to measure the sap flow during the wetting and drying of plants. Therefore, this study aimed to evaluate the capability of the sap flow sensors to measure the sap flow and hence transpiration during wetting (sprinkler irrigation) and drying including determination of any time lag between transpiration and sap flow under these conditions.

\section{Materials and Methods}

\subsection{Theory of the Heat Balance Method of Sap Flow}

The method is based on the application of a heat balance to a section of stem. The stem is heated electrically and the heat balance is solved for the amount of heat taken up by the moving sap stream which is then used to calculate the mass flow of sap in the stem.

The xylem sap flow rate $(F)$ is calculated from the following (Baker and Nieber, 1989);

$$
F=\left[\frac{P_{i n}-K_{s t} A\left(d t_{u}+d t_{d}\right) / d x-\left(K_{s h} d t_{r}\right)}{C_{p} d T}\right]
$$

Where $P_{\text {in }}$ is the input power (W), $K_{s t}$ is the thermal conductivity of the stem (W m- ${ }^{\circ} \mathrm{C}-1$ ), is the cross-sectional area of the heated section of the stem $\left(\mathrm{m}^{2}\right), d t_{u}$ is the temperature difference of two thermocouples above the heater $\left({ }^{\circ} \mathrm{C}\right), d t_{d}$ is the temperature difference of two thermocouples below the heater $\left({ }^{\circ} \mathrm{C}\right), d x$ is the distance between the two junctions positioned both below and above the heater $(\mathrm{m}), K_{s h}$ is the effective thermal conductance of the sheath of materials surrounding the heater $\left(\mathrm{W}{ }^{\circ} \mathrm{C}-1\right), d t_{r}$ is the temperature difference of two thermocouples radially $\left({ }^{\circ} \mathrm{C}\right), C_{p}$ is the xylem heat capacity $\left(4.186 \mathrm{~J} \mathrm{~g}-1{ }^{\circ} \mathrm{C}-1\right)$ and $d T=\left(d t_{u}+\right.$ $\left.d t_{d}\right) / 2 * 0.04$ is the temperature difference across the heater $\left({ }^{\circ} \mathrm{C}\right)$.

\subsection{Sap Flow and Transpiration Measurements}

The accuracy of the digital dynagage sap flow sensor (SGA10, Dynamax Inc. TX, USA) was tested in a glasshouse of the University of Southern Queensland, Toowoomba, Australia. Pot plants, Tulipwood (Harpullia pendula) with trunk diameters ranging from approximately 10 to $13 \mathrm{~mm}$ were used as test plants. These were chosen because their long straight stems were ideal for installation of the sap flow gages. During the tests, the plants were kept well watered at all the times. The gages sensors were protected from corrosion by an electrical insulating compound placed between the gages interior and the plant stem, and the exterior of the gage was covered with additional foam insulation, plastic wrap, and aluminium foil for thermal insulation. The gages were checked weekly to remove moisture build-up and to assess damage to plant stems and/or gages.

The evaluation of the sap flow measurements was conducted through valid comparisons between the sap flow and the rate of transpiration measured using load cell based weigh pads 


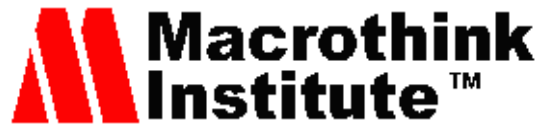

(22 kg capacity) which measured the weight loss of the pot plants over time, thus converting the plant pots into mini-lysimeters (Figure 1). The soil surface of the pots was covered with polythene to block the soil evaporation. Pot mass was continuously monitored by the load cells whose output was monitored by the data logger (CR3000, Campbell Scientific, Inc, Logan, UT, USA). The signals from the load cells were sampled every second and averaged over 5 minute time intervals.

The sap flow was recorded using a Smart data logger (ITC International, Australia) and was also sampled at 1 minute intervals (minimum as specification) and averaged over 5 minute time intervals. As the sensors contained a digital interface, the value of applied power $\left(P_{\text {in }}\right)$ of 100 $\mathrm{mW}$ was constant and a value of $0.42 \mathrm{Wm}^{-1} \mathrm{~K}^{-1}$ was adopted for the stem conductivity of woody plants (Sakuratani, 1981; Baker and van Bavel, 1987).

Micro-meteorological data ( $\mathrm{RH}$ and air temperature) were measured by a temperature and relative humidity probe (model HMP 45C, Campbell Scientific, Inc, Logan, UT, USA) using the same data logger as the lysimeters, to observe the effects of those variables on sap flow and transpiration. The canopy temperature of the plants was measured by infrared thermometer (4000L, ITC International Ltd, Australia). To study the effect of canopy wetting on sap flow and transpiration, the plants were wetted (spray irrigation) at different intervals using a small spray bottle.



Figure 1. Pot plants with sap flow gages installed and placed on weigh pads

\subsection{Calibration of the Lysimeters}

Before using the mini-lysimeters for measuring the weight loss of the potted plants, each lysimeter was required to calibrate in order to convert the voltage signal $\left(\mathrm{mV} \mathrm{V}^{-1}\right)$ data into actual load or weight. Accordingly, the load cells were calibrated using a set of loads within the range of 0 to $10.5 \mathrm{~kg}$ inclusive. During calibration of the lysimeters, the weight of the desired load was first measured on an electronic platform balance of $32 \mathrm{~kg}$ capacity. For a given load, the load cell signal $\left(\mathrm{mV} \mathrm{V}^{-1}\right.$ ) was measured by data logger (CR 3000, Campbell Scientific Ltd., 


\section{Macrothink

USA) at $1 \mathrm{sec}$ intervals and then averaged over 5 mins and plotted against the load ( $\mathrm{g}$ ). The worst case error for load cell balance was approximately $\pm 5 \mathrm{~g}$. From the calibration data, a regression of load $(\mathrm{g})$ against signal $\left(\mathrm{mV} \mathrm{V}^{-1}\right)$ for each load cell was drawn with coefficient of determination, slope and intercept parameters of the regression equations. These parameters were then used in the data logger program to estimate the pot weights $(\mathrm{g})$.

\subsection{Measurements of Sheath Conductance $\left(K_{\text {sh }}\right)$}

An excel spreadsheet was used to calculate the effective thermal conductance of the sheath materials surrounding the heater $\left(K_{s h}\right)$. The heater impedance, stem area, canopy temperature $\left(T_{c}\right)$, and thermal constant data were used, to verify the value of $K_{s h}$ calculated by the data logger using its inbuilt program. In that case, the average value of $K_{s h}$ in a predawn period (generally 4:00-6:00 AM) was considered as the value of $K_{s h}$ for subsequent days in calculating sap flow rate. The manually calculated and data logger estimated $K_{s h}$ values were found to be the same and hence, the auto adjusted option for $K_{s h}$ in the data logger was used to calculate the sap flow rate.

\section{Results and Discussion}

\subsection{Heat Balance Components}

Figure 2 represents the diurnal partition of input power $(0.11 \mathrm{~W})$. From the figure it is seen that the input power was constant over the entire day. Vertical conduction of heat above $\left(d t_{u}\right)$ and below $\left(d t_{d}\right)$ the heater was low at all the times except near midday. Depending on the time of day, most of the heat loss was associated with radial heat flux or heat transfer to the sap. Figure 2 illustrates that the vertical and radial conductive heat flux were lowest during the middle of the day, reflecting the substantial contribution of the xylem water in transporting heat. At night most of the heat loss was through vertical and especially radial conduction, with the values of radial conduction greater than the axial. Heat fluxes were relatively constant during the early morning hours when sap flow was low. 

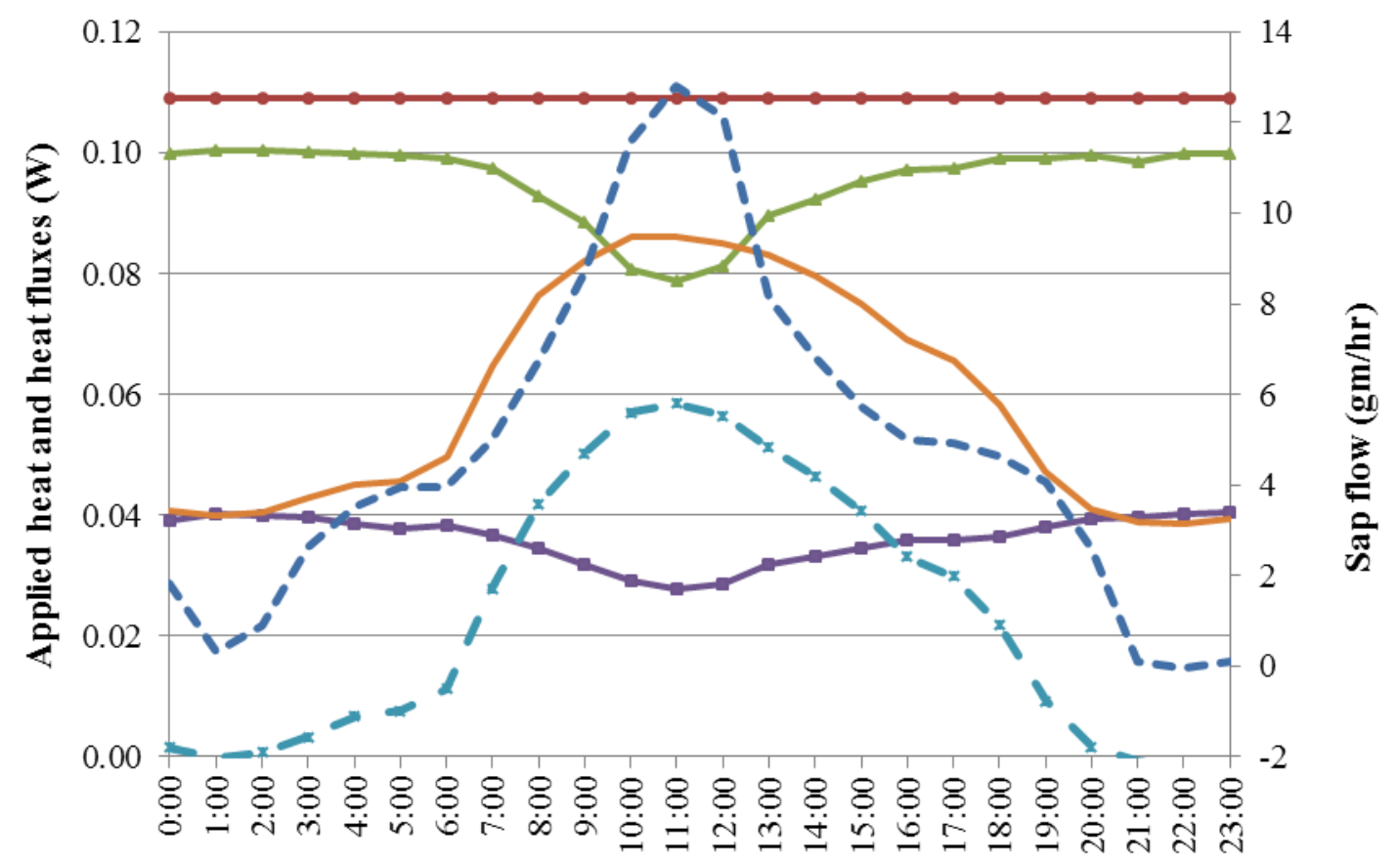

Time (hr)

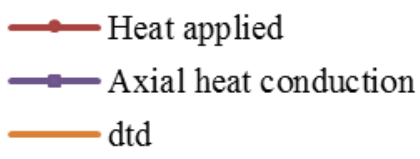

$$
\begin{aligned}
& - \text { Radial Heat conduction } \\
& -x-\text { dtu } \\
& -\infty-\text { Sap flow }
\end{aligned}
$$

Figure 2. Hourly values of each term of the heat balance in the plant stem on 15 September 2010 (DOY 258)

\subsection{Diurnal Pattern of Sap Flow and Transpiration}

The diurnal pattern of 5 min averaged sap flow and transpiration of the plants with a dry canopy is presented in Figure 3. The Figure shows that the sap flow and transpiration follow the same trend over the period with no obvious time lag between transpiration and sap flow. Under the greenhouse conditions, the sap flow and transpiration increased throughout the day peaking mid-afternoon, followed by an expeditious decline in the late afternoon as shown in Figure 3. Although the mean values of transpiration displayed considerable variation, the peak rates of transpiration appear to be higher than the equivalent peak rates of sap flow. After midnight the sap flow exceeded the transpiration rate slightly until the transpiration began its rapid increase the next morning. Ignoring the possibility of the night-time sap flow measurements being in error, one possible reason was given by Kumagai et al., (2009). They demonstrated that sap flow continued to replenish stem water storage throughout the night and early morning even though the transpiration was near zero. Stem water storage reached its maximum value by early morning, declining to a minimum by late afternoon as a result of the daytime transpiration. A similar fashion was noticed by Dugas (1990) in comparative measurements of stem flow and transpiration in glasshouse grown cotton. 


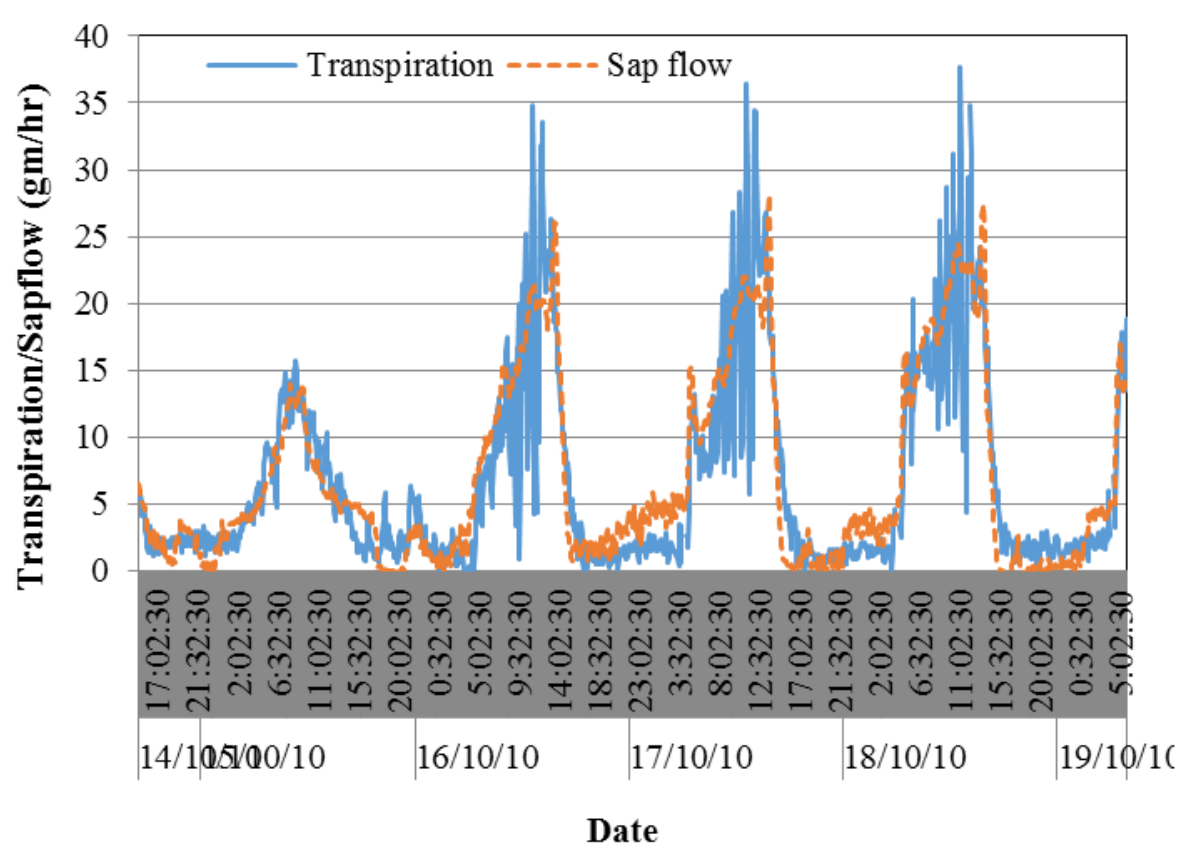

Figure 3. Diurnal pattern of 5 min averaged sap flow $(F)$ and transpiration $(T)$

The measurements of sap flow and transpiration averaged over different time intervals are shown in Figure $3 \& 4$. The fluctuations in the transpiration rate strongly evident in the 5 min averaged data decreased with increasing averaging time. The changes in transpiration rate that were shorter therefore disappeared or were not fully reflected in the sap flow measurements (Figure 3). The resulting transpiration rates were more consistent with increased averaging time. The sap flow data did not exhibit significant short time fluctuations. Figures $4 a \& 4 b$ show that the agreement between sap flow and transpiration was much better with the longer time averaged values than the shorter time averaged values. Standard error decreased from 2.11 to 1.48 with increasing averaging time from 5 minutes to 60 minutes. Averaging the transpiration data over 30 to $60 \mathrm{~min}$ resulted in a sufficient reduction of scatter as all the rapid changes in transpiration are evened out by the integration over these longer time intervals (Figure $4 \mathrm{a} \& 4 \mathrm{~b}$ ). Moreover, it increased the accuracy for the given time interval significantly. As the longer time averages gave better results, the further data analysis was carried out using the 60 minute averages. 


\section{I Macrothink}

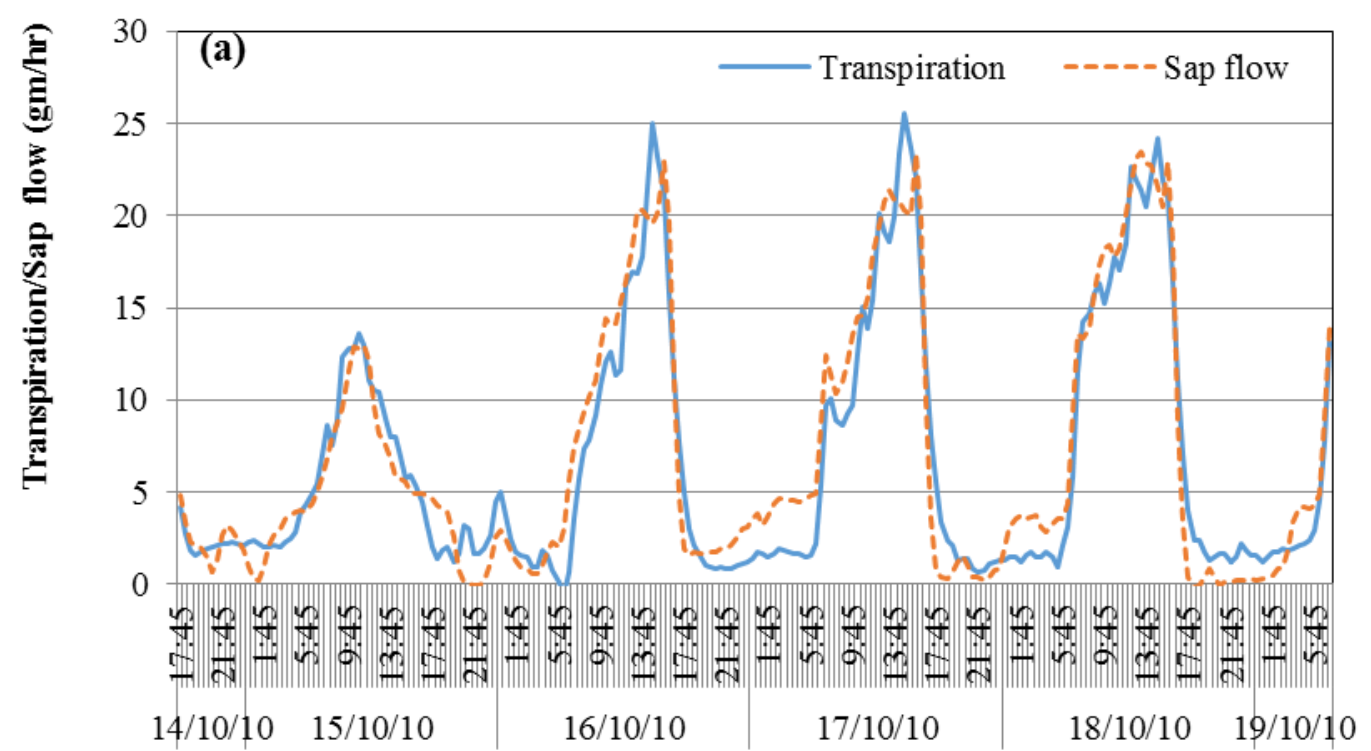

Date

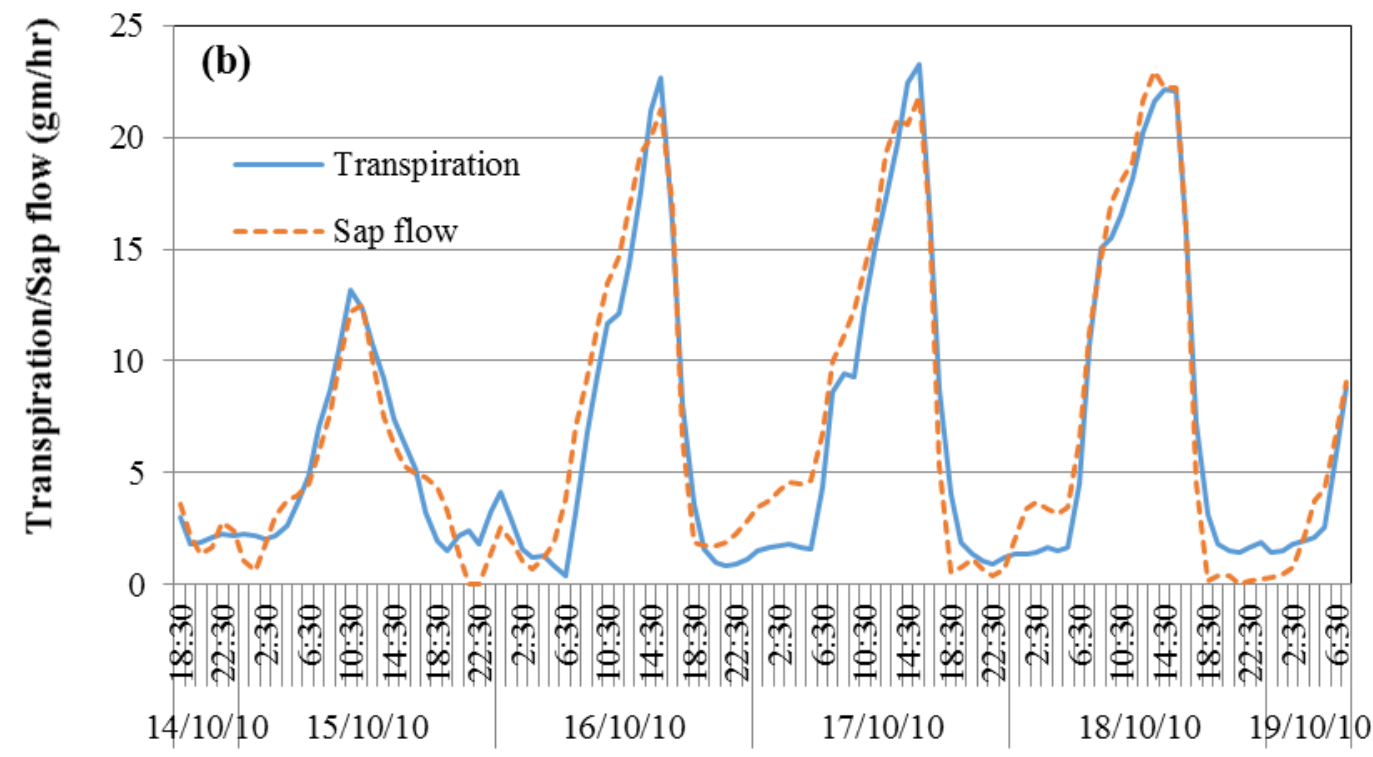

Date

Figure 4. Effect of averaging time on sap flow and transpiration (a) $30 \mathrm{~min}$ averages (b) $60 \mathrm{~min}$ averages

\subsection{Comparison of Daily Values}

Figure 5 shows the daily values of sap flow and transpiration for the four days 15 to 18 October 2010. The figure illustrates that sap flow measurements overestimated the transpiration on all days except 15 October. The average values of sap flow and transpiration over the period were $6.91 \mathrm{gm} \mathrm{hr}^{-1}$ and $6.25 \mathrm{gm} \mathrm{hr}^{-1}$, respectively. Hence the sap flow overestimated transpiration by 
about 11\%. Many authors (e.g. Dugas, 1990; Ham et al., 1990) have also indicated that sap flow measured using this type of sensor under different conditions overestimates transpiration by $10-15 \%$. The root mean square difference (RMSD) between the two quantities was $1.47 \mathrm{gm}$ $\mathrm{hr}^{-1}$ which was $6.33 \%$ in terms of a normalized root mean square difference (NRMSD).



Figure 5. Daily average values of of sap flow $(F)$ and transpiration $(T)$

\subsection{Estimation of Time Lag}

In the data presented in Figures 3 to 4 show that there was no time lag in transpiration and sap flow measurements. This is not surprising given the relatively small size of the plants, although a time lag is common in transpiration and sap flow measurements usually attributed to the capacitance or water buffering capacity of the plant (Fichtner and Schulze, 1990; Kostner et al., 1998; Schulze et al., 1985). Nevertheless, this time lag is most significant for large trees, for example, Kumagai et al. (2009). However, Weibel and Vos (1994) as well as Grime et al. (1995) demonstrated that such a time lag can also occur for heat balance systems when heat storage components are neglected. Braun and Schimd (1999) indicated that the possible cause for such an effect might be the thermal mass of the sensor itself. A change in heat transfer from the sensor and the surrounding areas to the xylem stream will take some time before it affects the inner part of the sensor.

\subsection{Effect of Wetting on Sap Flow and Transpiration}

The effect of sprinkler irrigation (canopy wetting) on the sap flow was studied in different ways. In the first trial the plant canopy was periodically wetted instantaneously followed by a drying period of one hour. The effect of canopy wetting on the sap flow is shown in Figure 6. From the figure it is seen that after wetting the plant canopy, the sap flow declined evenly and reached at its minimum value about 20 min later in almost all cases. After that time the sap flow started to increase as the canopy dried and recovered to about its initial value at around 40 mins. 


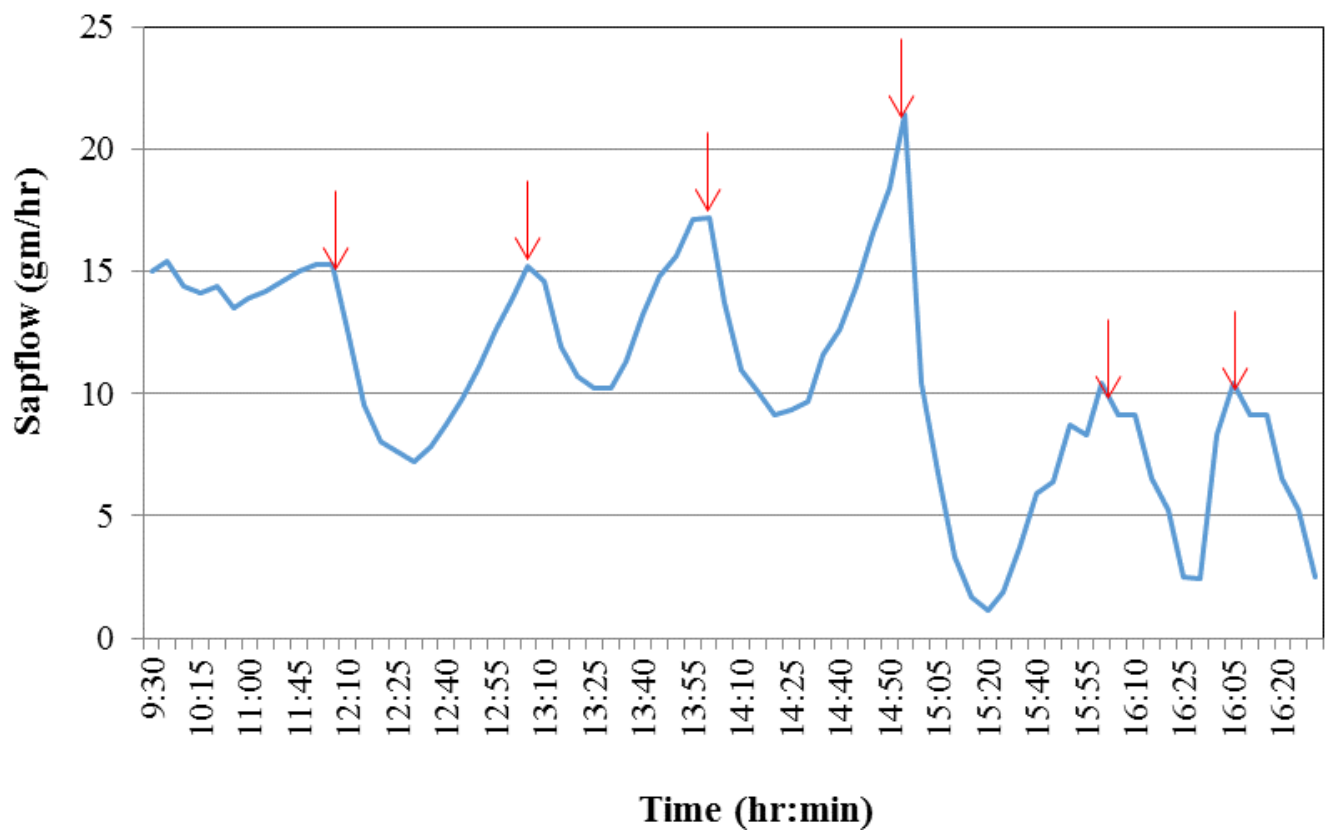

Figure 6. Effect of canopy wetting on sap flow on 15 September 2010 ( DOY 258)

( $\downarrow$ indicates the time of wetting the plant)

For continous wetting for 30 mins, the sap flow followed the same trend as in the previous trial, but the effect of wetting on the sap flow was longer, remaining at the lowest value for about 30 mins. After that the sap flow started to rise and recovered after about a further 35 mins (Figure 7).

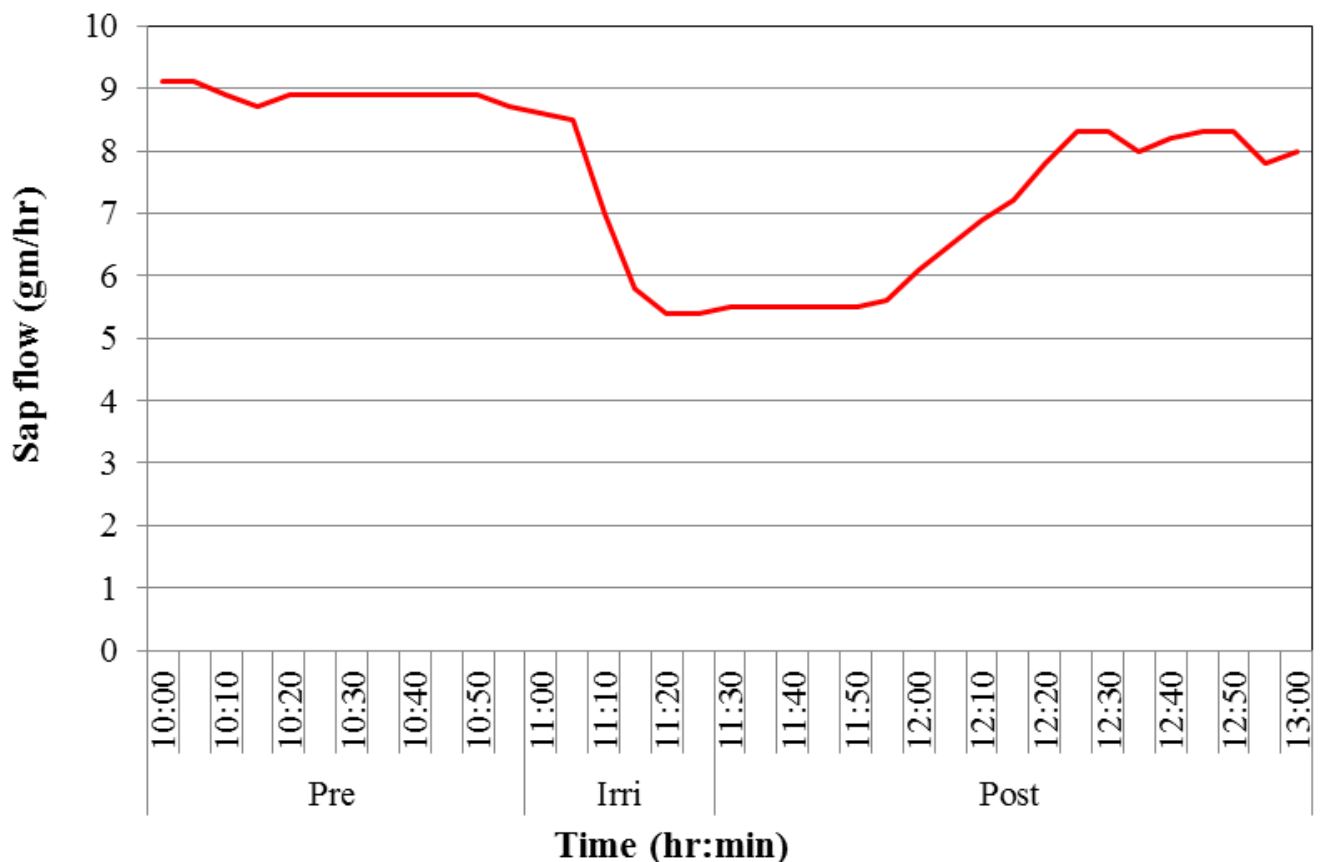

Figure 7. Effect of irrigation on sap flow on 17 September 2010 ( DOY 260) for a one half hour irrigation 


\section{Ml Macrothink}

The use of the mini-lysimeters provided a different perspective on the water loss following wetting (Figure 8). The rate of water loss immediately following the canopy wetting (spray irrigation) was very much higher than the sap flow due to the evaporation of the free water intercepted by the plant canopy but declined rapidly to the transpiration rate as the canopy dried. After complete drying of the canopy the sap flow and transpiration were again at a similar rate.

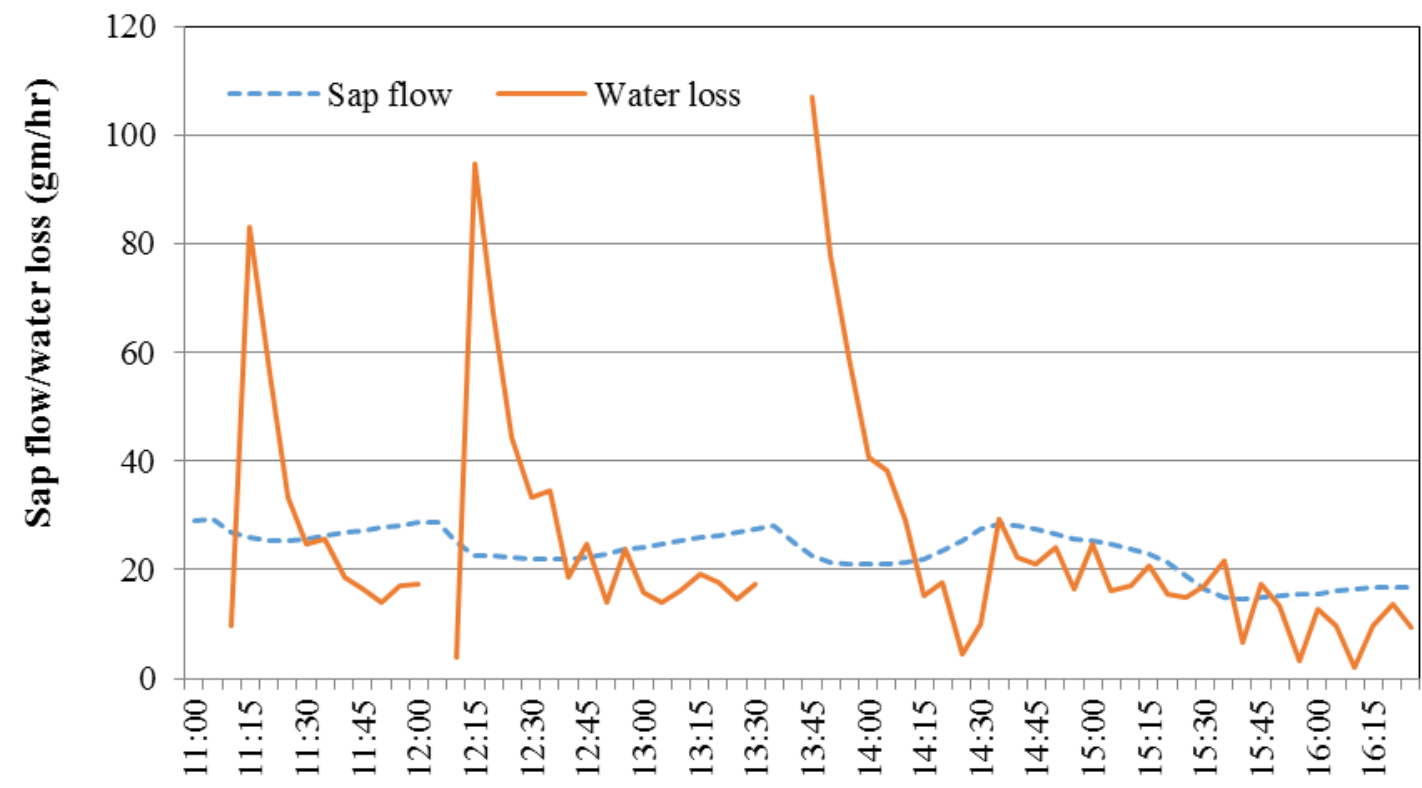

Time (hr:mm)

Figure 8 . The rate of sap flow and water loss following wetting of the plant ( $\downarrow$ indicates the time of wetting of the plant canopy)

\subsection{Effect of Gage Position on the Stem on Sap Flow Measurements}

To further assess the accuracy of the sap flow gages two gages were installed at different heights on the same plant stem and the plant subjected to alternate periods of wetting and drying. The sap flow at the two different heights in the stem (Figure 9) followed the same pattern as in Figure 7, however the amplitude of the variation was different for each gage, being least at the lower position.

This difference in sap flow at different heights on the plant stem was confirmed by reversing the position of the two gages on the stem on two consecutive days. Figure 10 shows that the upper sensor measured higher sap flow (sensor a on 3 October and sensor $\mathrm{u}$ on 5 October 2010) than the lower sensor (sensor $u$ on 3 October and sensor a on 5 October 2010). This was attributed to the storage and buffering capacity of the stem. Kumagai et al. (2009) found a similar trend for trees. 




Time (hr:min)

Figure 9. The response of sap flow due to wetting for gages installed at different heights on the plant stem on 27 September 2010 (DOY 270)

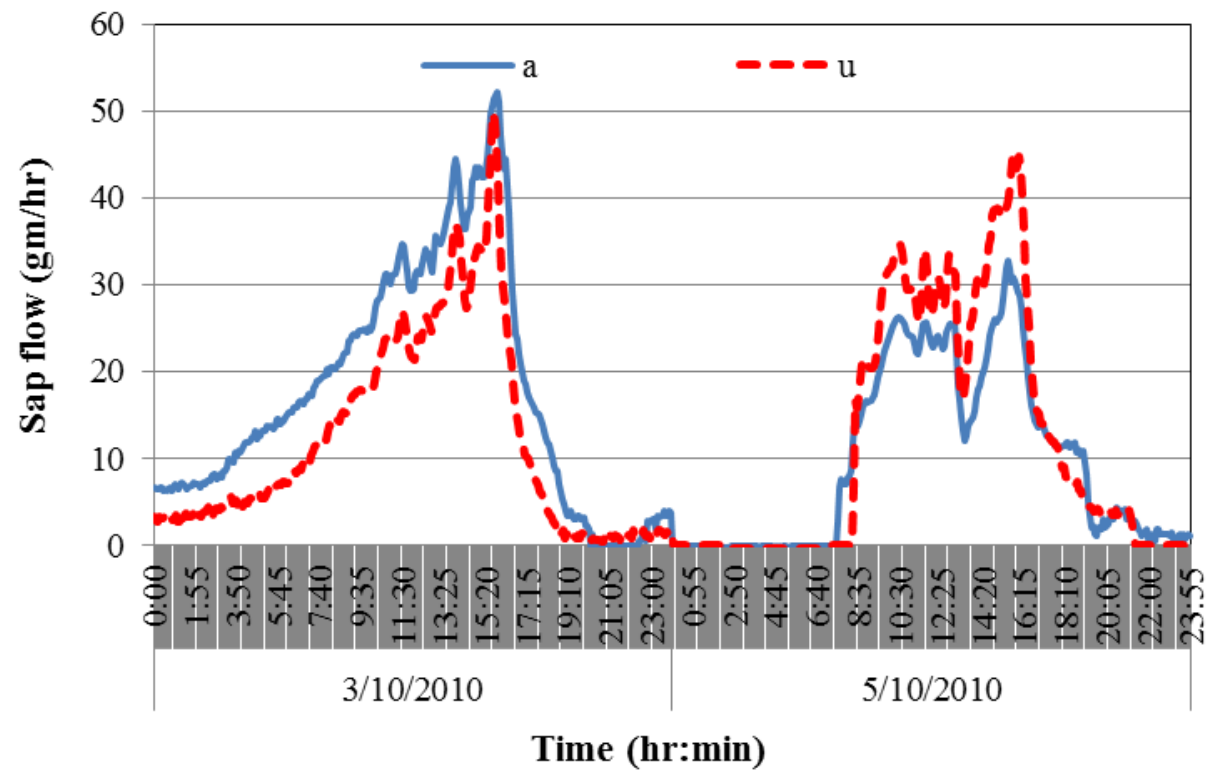

Figure 10. Sap flow at two heights in the same plant - gauge positions were reversed on the second day

\subsection{Effect of Meteorological Variables on Sap Flow and Transpiration}

The meteorological variables (air temperature, canopy temperature, relative humidity $(\mathrm{RH})$ and vapour pressure deficit (VPD), and the resulting transpiration and sap flow are plotted in Figure 11 over a period of five days. From the figure it is seen that as expected the sap flow and transpiration are directly proportional to the air temperature, canopy temperature \& VPD and inversely proportional to the $\mathrm{RH}$. 


\section{Macrothink}

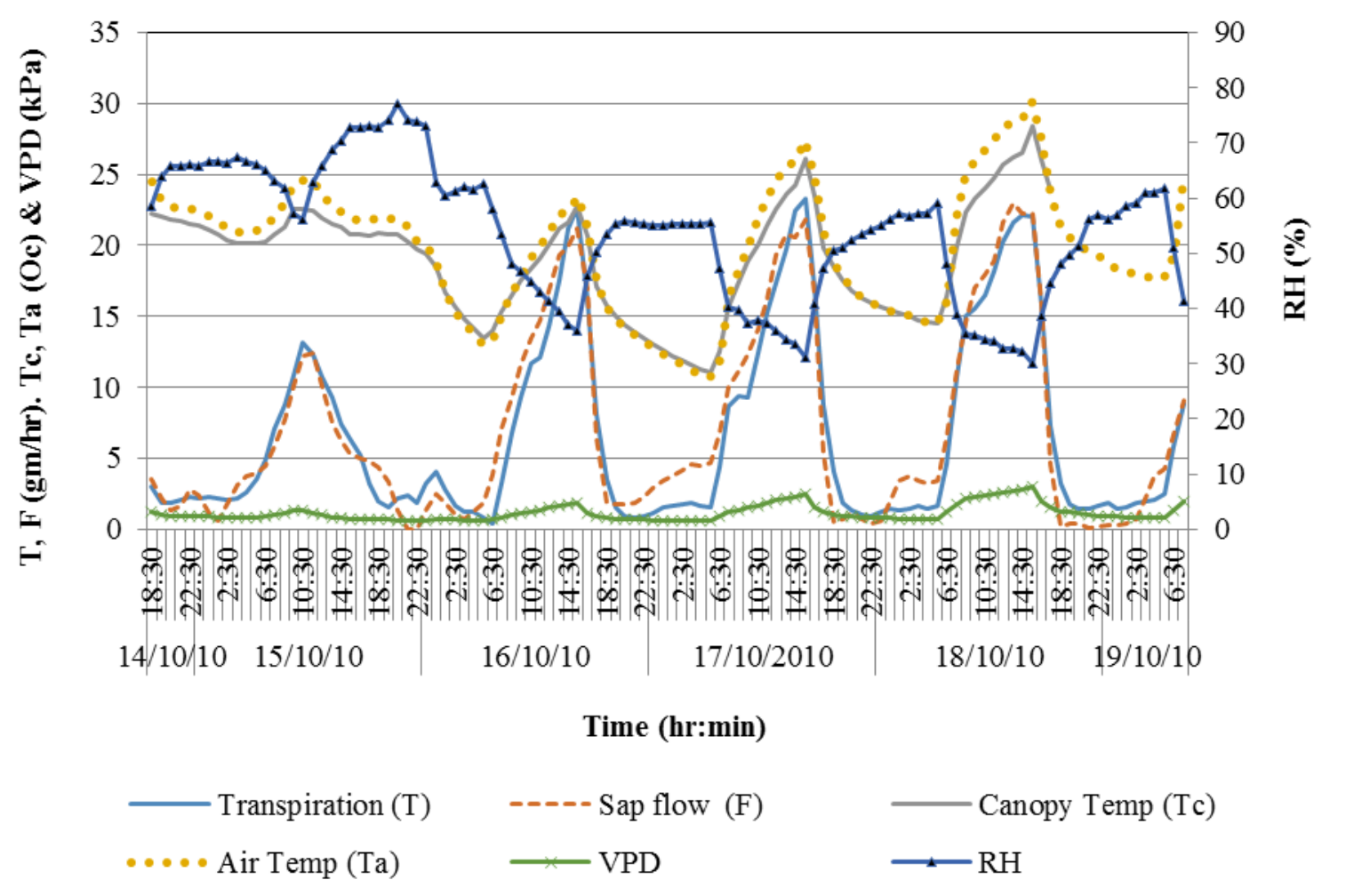

Figure 11. Effect of meteorological variables on sap flow and transpiration

\section{Conclusions}

From this study it is shown that when the canopy was dry the sap flow and transpiration rates followed a similar pattern. However, it was found that the sap flow overestimated the transpiration rate by approximately $11 \%$ on hourly basis while it was about $7 \%$ on daily basis. When the plant canopy was artificially wetted to simulate the effect of sprinkler irrigation, the sap flow reduced substantially (reflecting a drop in transpiration) before returning to its original value as the canopy dried. In the absence of any method to measure transpiration during periods of canopy wetting, the sap flow measurements are seen as an appropriate surrogate for transpiration. During this wetting period the rate of evaporation from the plant canopy was very much higher than the dry canopy transpiration rate, due to the extra evaporation of the free water intercepted on the canopy.

\section{References}

Baker, J., \& Bavel, C. H. M. (1987). Measurement of mass flow of water in the stems of herbaceous plants. Plant, Cell \& Environment, 10(9), 777-782.

Baker, J., \& J. Nieber (1989). An analysis of the steady-state heat balance method for measuring sap flow in plants. Agricultural and Forest Meteorology, 48(1-2), 93-109. http://dx.doi.org/10.1016/0168-1923(89)90009-9

Braun, P., \& Schmid, J. (1999). Sap flow measurements in grapevines (Vitis vinifera L.) 2. Granier measurements. Plant and Soil, 215(1), 47-55. http://dx.doi.org/10.1023/A:1004708119821 
Cavero, J., Medina, E., Puig, M., \& Martínez-Cob, A. (2009). Sprinkler irrigation changes maize canopy microclimate and crop water status, transpiration, and temperature. Agronomy Journal, 101(4), 855. http://dx.doi.org/10.2134/agronj2008.0224x

Chabot, R., Bouarfa, S., Zimmer, D., Chaumont, C., \& Moreau, S. (2005). Evaluation of the sap flow determined with a heat balance method to measure the transpiration of a sugarcane $\begin{array}{llll}\text { canopy. } \quad \text { Agricultural } & \text { Water }\end{array}$ http://dx.doi.org/10.1016/j.agwat.2004.12.010

Dugas, W. (1990). Comparative measurement of stem flow and transpiration in cotton. Theoretical and Applied Climatology, 42(4), 215-221. http://dx.doi.org/10.1007/BF00865981

Fichtner, K., \& Schulze, E. D. (1990). Xylem water flow in tropical vines as measured by a $\begin{array}{llll}\text { steady state } \text { heating } \text { method. } & \text { 355-361. }\end{array}$ http://dx.doi.org/10.1007/BF00317483

Grime, V. L., Morison, J. I. L., \& Simmonds, L. P. (1995). Including the heat storage term in sap flow measurements with the stem heat balance method. Agricultural and Forest Meteorology, 74(1-2), 1-25. http://dx.doi.org/10.1016/0168-1923(94)02187-O

Ham, J., \& Jay, M. (1990). Determination of soil water evaporation and transpiration from energy balance and stem flow measurements. Agricultural and Forest Meteorology, 52(3-4), 287-301. http://dx.doi.org/10.1016/0168-1923(90)90087-M

Kostner, B., Schulze, E. D., Kelliher, F., Hollinger, D., Byers, J., \& Hunt, J. (1992). Transpiration and canopy conductance in a pristine broad-leaved forest of Nothofagus: an analysis of xylem sap flow and eddy correlation measurements. Oecologia, 91(3), 350-359. http://dx.doi.org/10.1007/BF00317623

Kumagai, T., Aoki, S., Otsuki, K., \& Utsumi, Y. (2009). Impact of stem water storage on diurnal estimates of whole-tree transpiration and canopy conductance from sap flow measurements in Japanese cedar and Japanese cypress trees. Hydrological Processes, 23, 2335-2344. http://dx.doi.org/10.1002/hyp.7338

Lawrence, D., Thornton, P., Oleson, K., \& Bonan, G. (2007). The partitioning of evapotranspiration into transpiration, soil evaporation, and canopy evaporation in a GCM: impacts on land-atmosphere interaction. Journal of Hydrometeorology, 8, 862-880. http://dx.doi.org/10.1175/JHM596.1

Martinez-Cob, A., Playan, E., Zapata, N., Cavero, J., Medina, E., \& Puig, M. (2008). Contribution of evapotranspiration reduction during sprinkler irrigation to application efficiency. Journal of Irrigation and Drainage Engineering, 134(6), 745-757. http://dx.doi.org/10.1061/(ASCE)0733-9437(2008)134:6(745)

Sakuratani, T. (1981). A heat balance method for measuring water flux in the stem of intact plants. Agricultural Meteorology, 37(1), 9-17. http://dx.doi.org/10.2480/agrmet.37.9

Schulze, E. D., Ermak, J., Matyssek, M., Penka, M., Zimmermann, R., \& Vasicek, F. (1985). Canopy transpiration and water fluxes in the xylem of the trunk of Larix and Picea trees-a 


\section{Macrothink}

Journal of Agricultural Studies

ISSN 2166-0379

2014, Vol. 2, No. 2

comparison of xylem flow, porometer and cuvette measurements. Oecologia, 66(4), 475-483. http://dx.doi.org/10.1007/BF00379337

Smith, D., \& Allen, S. (1996). Measurement of sap flow in plant stems. Journal of Experimental Botany, 47(12), 1833. http://dx.doi.org/10.1093/jxb/47.12.1833

Swanson, R. H. (1994). Significant historical developments in thermal methods for measuring sap flow in trees. Agricultural and Forest Meteorology, 72(1-2), 113-132. http://dx.doi.org/10.1016/0168-1923(94)90094-9

Thompson, A. L., Martin, D. L., Norman, J. M., Tolk, J. A., Howell, T., \& Gilley, J. (1997). Testing of a water loss distribution model for moving sprinkler systems. Transactions of the ASAE, 40(1), 81-88. http://dx.doi.org/10.13031/2013.21251

Weibel, F. P., \& Vos, J. A. D. (1994). Transpiration measurements on apple trees with an improved stem heat balance method. Plant and Soil, 166, 203-219. http://dx.doi.org/10.1007/BF00008334

\section{Copyright Disclaimer}

Copyright for this article is retained by the author(s), with first publication rights granted to the journal.

This is an open-access article distributed under the terms and conditions of the Creative Commons Attribution license (http://creativecommons.org/licenses/by/3.0/). 